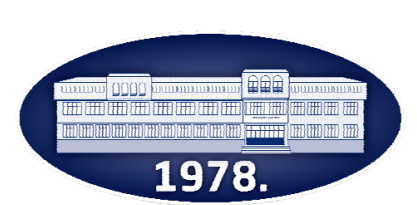

Publisher: Faculty of Agronomy Čačak

\title{
Relationship of earthworm biomass with temperature and rainfall in cultivated coconut and cinnamon lands in Sri Lanka
}

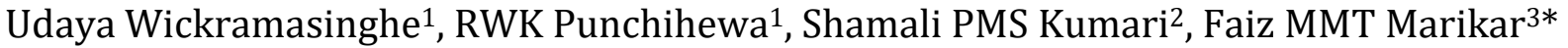 \\ ${ }^{1}$ Faculty of Agriculture, University of Ruhuna, Mapalana, Sri Lanka \\ ${ }^{2}$ Department of Basic Sciences, Faculty of Health Sciences, The Open University of Sri Lanka \\ ${ }^{3}$ Staff Development Center, General Sir John Kotelawala Defense University, Ratmalana, Sri Lanka \\ *Corresponding author: faiz.marikar@fulbrightmail.org
}

Received 30 August 2020; Accepted 9 November 2020

\begin{abstract}
A B S T R A C T
Earthworms are keystone detritivores that can influence primary producers by changing seedbed conditions, soil characteristics, flow of water, nutrients and carbon, and plant-herbivore interactions. Our objective was to understand the impact of weather conditions on the number of species found and the relationship between the biomass and temperature and rainfall conditions in cultivated coconut and cinnamon lands in Sri Lanka. Earthworms were collected from Hakmana, Walasmulla, and Deiyandara districts from Sri Lanka. In this study we found a significant relationship between earthworm biomass and temperature in cinnamon soil, but there was no significant difference related to temperature and rainfall in coconut lands compared with cinnamon lands. The correlation between earthworm biomass and rainfall was weak. Also, we found no relationship between the number of species and temperature and rainfall conditions. The results indicated that the number of species was reduced due to climate change and that cinnamon lands provided good conditions for earthworms.
\end{abstract}

Keywords: earthworm, cinnamon, coconut, climatic condition, Sri Lanka.

\section{И 3 В О д}

Глисте су кључни детритивори који могу утицати на примарне пољопривредне произвођаче променом сетвених услова, карактеристика земљишта, протока воде, хранљивих састојака и угљеника и интеракције биљака - биљојед. Циљ рада је био да се објасни утицај временских услова на број пронађених врста, као и однос између биомасе и температуре у кишним условима у засадима кокоса и цимета на Шри Ланки. Глисте су сакупљене из округа Хакмана, Валасмулла и Деииандара са Шри Ланке. У овој студији пронађена је значајна веза између биомасе глиста и температуре у тлу у засаду цимета, али није било значајне разлике у вези са температуром и количином падавина у засаду кокоса у поређењу са засадом цимета. Корелација између биомасе глиста и количине падавина је била слаба. Такође, није утврђена значајна веза између броја врста глиста и температуре и количине падавина. Резултати су показали да је број врста глиста смањен због климатских промена и да су земљишта на којима се гаји цимет пружала добре животне услове за глисте.

Кључне речи: глиста, цимет, кокос, климатски услови, Шри Ланка.

\section{Introduction}

The role of earthworms in the processes of decomposition, building and maintenance of soil structure has been well documented for soils of temperate climates. Ever since the late 1800 s, with the pioneering work of Hensen and Darwin, earthworms (EWs) have been known for their large "engineering" effects (Jones et al., 1994; Lavelle et al., 2016) on the chemistry and physical structure of soils. These effects include stimulation of litter and soil organic matter decomposition and soil nutrient mineralization, which can enhance soil nutrient availability (e.g., Lee, 1995; Edwards and Bohlen, 1996) and plant productivity (Curry, 1987; Scheu, 2003).

Extensive literature is available on earthworm ecology in temperate regions (Edwards and Bohlen, 1996; Reynolds, 1995). However, relatively less work is done in the tropical regions (Kale, 1997; Tripathi and Bhardwaj, 2004; Singh et al., 2019). In another series of studies in Mexican forests, Lavelle and Kohlmann (1984) and Fragoso and Lavelle (1987) found higher abundances of earthworms, mainly endogenic-soil feeders, suggesting that earthworms probably have an important role in soil dynamics.

Earthworms play an important role in nutrient cycling and in the development of micro-morphological structure for soils in which they are active (Bostrom and Lofs-Holmin 1986; Pawluk, 1987; Medina-Sauza et al., 2019). The linkages between earthworm activity, biotic and abiotic factors, climate change and land management practices are numerous, interrelated, and in many cases shape ecosystem service provision. Therefore, the objectives of the present study were to quantify the effects of EW species and biomass with respect to rainfall and temperature to evaluate whether earthworms induced any changes to the plant communities with respect to climate change. 


\section{Materials and Methods}

\section{Site Description}

Hakmana, Walasmulla and Deiyandara are located in the southern part of Sri Lanka, and their exact positions are as follows: Hakmana $6.0796^{\circ} \mathrm{N}, 80.6577^{\circ}$ E, Walasmulla $6.1509^{\circ} \mathrm{N}, 80.6937^{\circ} \mathrm{E}$ and Deiyandara $6.1526^{\circ} \mathrm{N}, 80.6029^{\circ}$ E. The area is covered with tropical and subtropical forests with an annual rainfall of $2500 \mathrm{~mm}$. Three agroforestry based experimental plots were laid down. In each agroforestry land, two basic crops grown in these regions were selected, i.e. cinnamon and coconut (Figure 1).
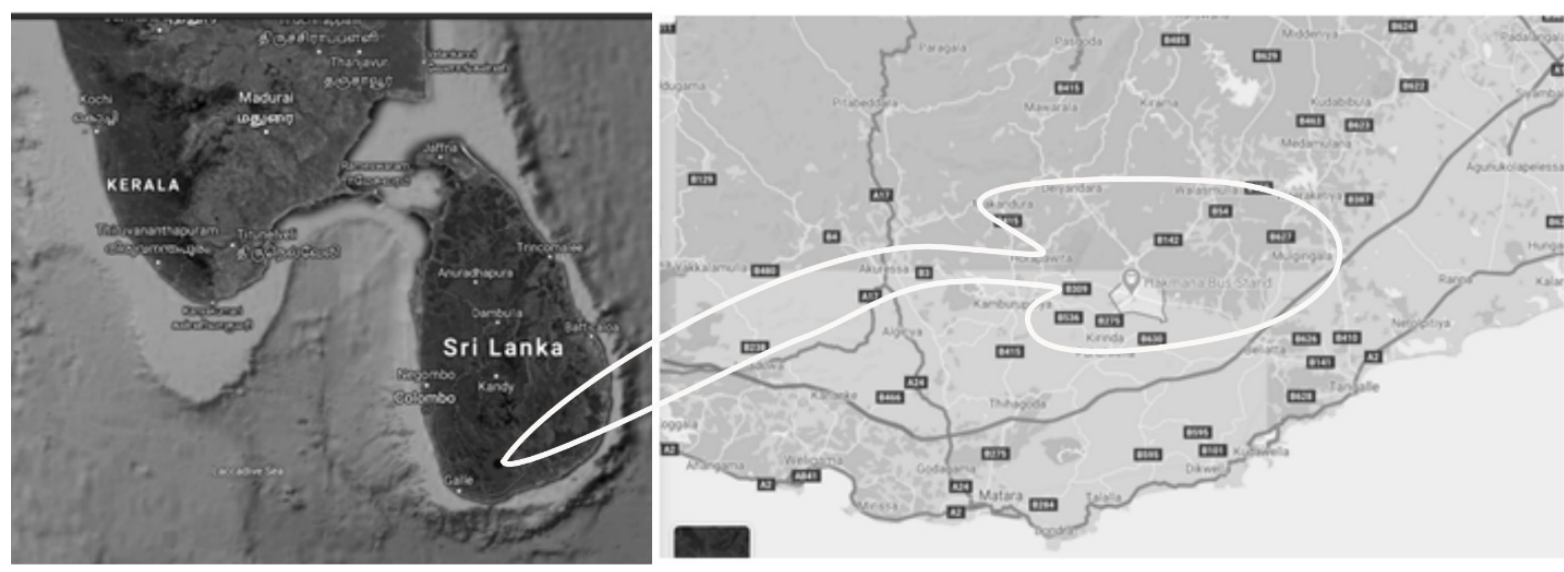

Figure 1. Map of the location and the study sites

\section{Earthworm sampling}

Earthworms were collected in the morning hours from five random samples of $25 \times 25 \times 30 \mathrm{~cm}$, at least $5 \mathrm{~m}$ apart at monthly (July 1999 to June 2020) intervals as per Tropical Soil Biology and Fertility Program (Anderson and Ingram, 1993). The worms were segregated age-wise and species-wise by the hand sorting and wet sieving method. Density of earthworms was calculated as the number of individuals present per square meter. Biomass was determined on a fresh weight basis (Dash and Patra, 1977). Monthly rainfall and temperature in the study areas were recorded throughout the study period.

\section{Calculations and statistical analysis}

The co-efficient of correlation ( $r$ ) was employed to find the relationship between earthworm density and biomass, on the one hand, and rainfall and temperature, on the other, and the data were calculated using the statistical package R.

\section{Results}

Correlation results are presented in Table 1 .

Table 1.

Pearson's correlation of earthworm biomass with respect to temperature and rainfall

\begin{tabular}{|l|l|l|l|l|l|}
\hline & & Temperature & & Rainfall & \\
\hline & & $\begin{array}{l}\text { Pearson's } \\
\text { Correlation }\end{array}$ & Sig (2-tailed) & $\begin{array}{l}\text { Pearson's } \\
\text { Correlation }\end{array}$ & Sig (2-tailed) \\
\hline Walasmulla & Cinnamon & $.642^{*}$ & .001 & -.147 & .493 \\
\hline & Coconut & .230 & .279 & -.055 & .798 \\
\hline Hakmana & Cinnamon & $.495^{* *}$ & .014 & -.174 & .416 \\
\hline & Coconut & .065 & .764 & -.157 & .464 \\
\hline Deiyandara & Cinnamon & $.515^{* *}$ & .010 & -.105 & .624 \\
\hline & Coconut & -.135 & .530 & .089 & .680 \\
\hline
\end{tabular}

${ }^{*}$ Correlation is significant at the 0.01 level (2-tailed)

** Correlation is significant at the 0.05 level (2-tailed)

In the Walasmulla region, there was a moderate correlation between earthworm biomass and temperature $(0.642)$ in the cinnamon land, and it was ignificant at the $1 \%$ significance level. A weak negative correlation was determined between biomass and rainfall. Weak and non-significant correlations were observed in the coconut land.

The analysis of the Hakmana region showed that the correlation between earthworm biomass and temperature was 0.495 , indicating a moderate correlation in the cinnamon land, significant at the $5 \%$ significance level. There was a weak negative correlation between biomass and rainfall in this region. Weak and non-significant correlations were observed in coconut land.

In the Deiyandara region, in cinnamon land, the correlation between earthworm biomass and temperature was 0.515 , indicating a moderate correlation, significant at the $5 \%$ significance level. There was a weak negative correlation between biomass and rainfall. When observing the coconut land, weak and non-significant correlations were determined. 
Overall, earthworm biomass was significantly correlated with temperature in cinnamon lands while week or no correlation was observed for rainfall. In coconut lands it was hard to see a relationship between earthworm and rainfall or temperature.

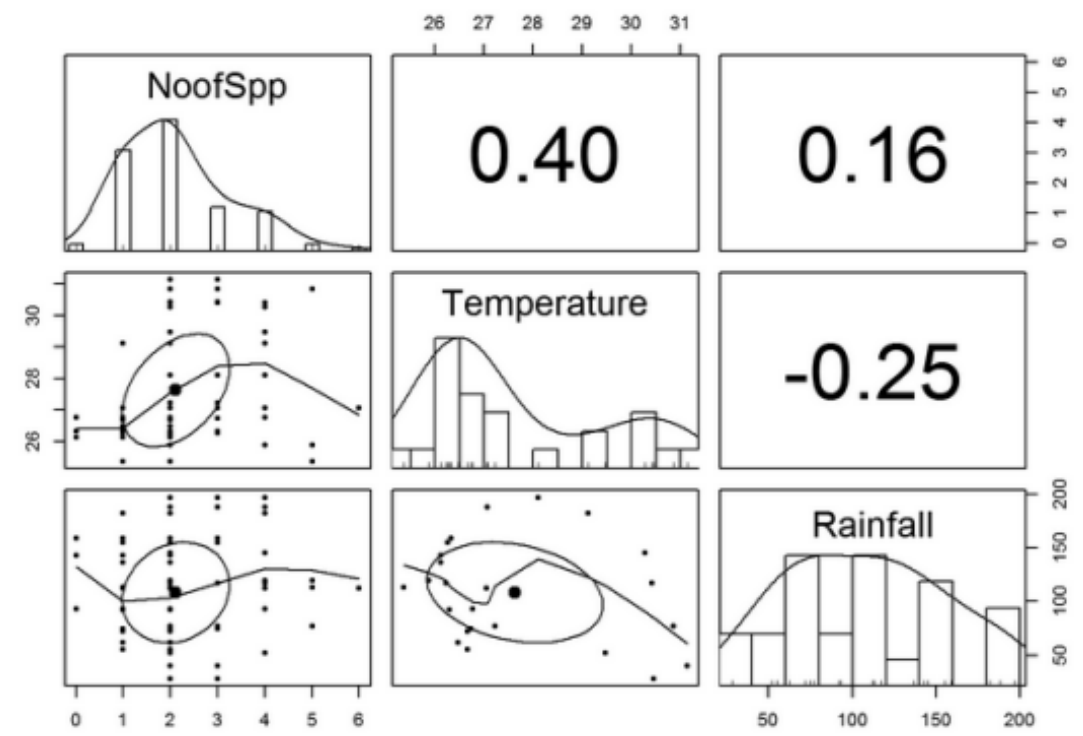

Figure 2. R statistical analysis to check the relationship of earthworm species with temperature and rainfall.

The relationship of the number of earthworm species with rainfall and temperature was analyzed by the $\mathrm{R}$ statistical package (Figure 2). It was observed that there was no relationship between the number of species and the environmental variables, i.e. temperature and rainfall.

\section{Discussion}

Temperature is one of the most important climate change drivers determining the activity of soil biota and decomposition processes. The chance of heavy rain events and flooding is increasing globally, as precipitation will be concentrated into more intense events with longer periods of little precipitation in between (Hennessy et al., 1997; Desie et al., 2020). Species richness and diversity of earthworm communities are not significantly different from those of temperate forests with respect to temperature and rainfall.

At a larger regional scale (earthworm diversity), however, tropical countries harbor more species than temperate ones; unfortunately, we could not find more due to climate change. Tropical rain forest earthworm communities have lower abundances and biomasses than temperate pastures (Lee, 1985) and tropical savannas and grasslands (Lavelle, 1983; SanchezHernandez et al., 2019). Due to global climate change we observed a weaker relationship between earthworm species and weather conditions, such as rainfall and temperature.

The results of our study conclusively show that cinnamon lands favored the growth of earthworms, as testified by the increase in their numbers. However, further studies are needed to confirm and elaborate on this speculation. Nonetheless, this synthesis may also have important implications for the management of agricultural fields and future research directions. First, there is empirical evidence that agricultural practices that stimulate soil biodiversity, such as increased crop diversity, reduced tillage, and continuous soil cover, could help mitigate the effects of climate change on earthworm communities. We emphasize the importance of context dependent climate change effects that are currently underexplored.

This study showed for the first time that, during climate change, earthworm densities were significantly affected in cinnamon lands, while this was not the case in coconut lands. Furthermore, this study revealed that there was no significant difference in earthworm species with respect to weather conditions, i.e. rainfall and temperature.

\section{Conclusions}

In spite of the fact that this paper explored three study sites in Sri Lanka, the findings showed that, in cinnamon lands, there was a significant difference in earthworm biomass related to temperature, but no difference related to rainfall. Furthermore, no relationship was observed between temperature or rainfall and earthworm density in coconut lands. The biotic relations observed indicate trophic interactions between earthworms, suggesting that land use management may have a top-down effect on trophic interactions that shape earthworm communities, or it may be due to climate change.

\section{References}

Anderson, J.M., Ingram, J.S.I. (1993). Tropical soil biology and fertility: a handbook of methods. Wallingford: CAB International, $2^{\text {nd }}$ ed., 221 p.

Bostrom, U., Lofs-Holmin, A. (1986). Growth of earthworms (Allolobophora caliginosa) fed shoots and roots of barley, meadow fescue and lucerne studies in relation to particle size, protein, crude fiber content and toxicity. Pedobiologia, 29(1), 1-12.

Curry, J.P. (1987). The invertebrate fauna of grassland and its influence on productivity. III. Effects on soil fertility and plant growth. Grass Forage Science, 42, 325-341.

Dash, M.C., Patra U.C. (1977). Density, biomass and energy budget of a tropical earthworm population from a 
grassland site in Orissa, India. Revue $d$ Ecologie et de Biologie du Sol, 14, 461-471.

Desie, E., Van Meerbeek, K., De Wandeler, H., Bruelheide, H., Domisch, T., Jaroszewicz, B., Joly, F.X., Vancampenhout, K., Vesterdal, L., Muys B. (2020). Positive feedback loop between earthworms, humus form and soil $\mathrm{pH}$ reinforces earthworm abundance in European forests. Functional Ecology. https://doi.org/10.1111/1365-2435.13668

Edwards, C.A., Bohlen P.J. (1996). Biology and Ecology of Earthworms. London: Chapman \&Hall.

Fragoso C. and Lavelie P. (1987). The earthworm community of a Mexican tropical rain forest (Chajui, Chiapas). In On Earthworms (A. M. Bonvincini Pagiai and P. Omodeo, Eds), 281-295. Mucchi, Modena.

Hennessy, K.J., Gregory, J.M., Mitchell, J.F.B. (1997). Changes in daily precipitation under enhanced greenhouse conditions. Climate Dynamics, 13(9), 667-680. Jones, CG Lawton, JH, and Shachak, M. (1994). Organisms as ecosystem engineers. Oikos 69, 373-386.

Kale, R.D. (1998). Earthworm: Cinderella of organic farming. Prism Books Pvt. Ltd. Bangalore, India.

Laveiie P. (1983). The soil fauna of tropical savannas. II. The earthworms. In Tropical Savannas (F. Bourliere, Ed.), pp. 485-504. Ecosystems of the World-13. Eisevier, The Netherlands.

Laveile, P., Kohimann B. (1984). Etude quantitative de la macro faune du sol dans une foret tropicale humide du Mexique (Bonampak, Chiapas). Pedobiologiu, 27, 377393.

Lavelle, P, Spain, A, Blouin, M, Brown, G, Decaëns, T., Grimaldi M. (2016). Ecosystem engineers in a self-organized soil: a review of concepts and future research questions. Soil Science, 181, 91-109.
Lee, K.E. (1969). Earthworms of the British Solomon Islands Protectorate. Philosophical Transactions of the Royal Society $B, 255,345-354$.

Lee, K.E. (1995). Earthworms and sustainable land use. In Earthworm Ecology and Biogeography in North America, ed. P.F. Hendrix (Boca Raton: Lewis Publishers), 215234.

Medina-Sauza, R.M., Álvarez-Jiménez, M., Delhal, A., Reverchon, F., Blouin, M., Guerrero-Analco, J.A., Cerdán, C.R., Guevara, R., Villain, L., Barois I. (2019). Earthworms building up soil microbiota, a review. Frontiers in Environmental Science, 7, 81-85.

Pawluk, S. (1987). Faunal micromorphological features in moder humus of some western Canadian soils. Geoderma, 40(1-2), 3-16.

Reynolds, J.W. (1995). The status of exotic earthworm systematics and biogeography in North America. In: Ecology and biogeography of earthworms in North America (Ed.: P.F. Hendrix). Lewis publishers, Boca Raton, 1-28.

Sanchez-Hernandez, J.C., Ríos, J.M., Attademo, A.M., Malcevschi, A., Cares X.A. (2019). Assessing biochar impact on earthworms: Implications for soil quality promotion. Journal of Hazardous Materials, 366, 582-591.

Singh, J., Schädler M., Demetrio, W., Brown, G.G., Eisenhauer N. (2019). Climate change effects on earthworms-a review. Soil organisms, 91(3), 114-118.

Schmidt, O. (2001). Appraisal of the electrical octet method for estimating earthworm populations in arable land. Annals of Applied Biology, 138, 231-241.

Tripathi, G., Bhardwaj P. (2004). Earthworm diversity and habitat preferences in arid regions of Rajasthan. Zoo's Print Journal, 19, 1515-1519. 